\title{
Obnova katoličkoga tiska u Hrvatskoj 1960-ih
}

\author{
ANTO MIKIĆ \\ Hrvatsko katoličko sveučilište \\ Zagreb, Hrvatska \\ anto.mikic@unicath.hr \\ MIRO RADALJ \\ Filozofski fakultet Sveučilišta u Mostaru \\ Mostar, Bosna i Hercegovina \\ miro.radalj@ff.sum.ba
}

\begin{abstract}
Oslanjajući se na objavljenu literaturu i neobjavljeno arhivsko gradivo, autori u radu obrađuju fenomen obnove katoličkoga tiska u Hrvatskoj tijekom 1960-ih, ponajprije u kontekstu crkveno-državnih odnosa toga vremena. Proces obnove Katoličke crkve, potaknut Drugim vatikanskom koncilom, s jedne strane te želja jugoslavenskih vlasti da ponovno normaliziraju odnose s Crkvom u tadašnjoj Jugoslaviji, ali i obnove 1952. jednostrano prekinute diplomatske odnose sa Svetom Stolicom s druge strane otvorili su mogućnost da Crkva u Hrvatskoj obnovi i neke svoje javne/društvene djelatnosti, koje su joj od 1945. bile sustavno uskraćivane, među kojima je istaknuto mjesto zauzelo ponovno pokretanje njezina tiska koji je država 1945. ugušila. Tu je priliku Crkva 1960-ih uspješno iskoristila, a obnovljeni katolički tisak naišao je na velik interes publike te su se u samo nekoliko godina umnožili i broj osnovanih/obnovljenih listova i njihova naklada.
\end{abstract}

Ključne riječi: Katolička crkva; komunističke vlasti; odnosi Sveta Stolica - Jugoslavija; katolički tisak; Glas Koncila

\section{Uvod}

Obnova katoličkoga tiska u Hrvatskoj, koji je dolaskom komunističke vlasti po završetku Drugoga svjetskog rata bio gotovo potpuno ugušen, fenomen je koji je hrvatska historiografija prepoznala i dijelom već obradila, barem na fenomenološkoj razini - navodeći pojedine katoličke listove pokrenute od 60-ih godina poput Glasa Koncila, Maloga koncila i Kane te njihov utjecaj, a dijelom i poteškoće na koje su nailazili. No u općim pregledima hrvatske povijesti druge polovine XX. stoljeća taj fenomen u pravilu ne zauzima neko istaknutije mjesto te ga se, poput primjerice kod Zdenka Radelića ${ }^{1}$, obrađuje

1 RADELIĆ, Hrvatska u Jugoslaviji, 375-378. 
kratko i, po našem sudu s pravom, stavlja u kontekst stanovite normalizacije odnosa između Crkve i države. Autori koji podrobnije proučavaju te odnose, poput Miroslava Akmadže, dijelom su rasvijetlili i neke epizode u životu toga tiska, poput pojedinih sudskih zabrana i zapljena državnih vlasti, ali i kritike na koje je povremeno nailazio unutar same Crkve zbog svojih reformskih nastojanja. ${ }^{2} \mathrm{U}$ pojedinim radovima poprilično su sustavno rekonstruirane i okolnosti osnivanja nekih važnijih crkvenih listova. ${ }^{3}$

Mi ćemo u ovome radu nastojati sažeti spoznaje spomenutih i drugih autora na temu obnove katoličkoga tiska u Hrvatskoj te ih staviti u kontekst crkveno-državnih odnosa u promatranome desetljeću XX. stoljeća. Obnova katoličkoga tiska, naime, po našem je sudu ponajprije rezultat upornosti Crkve u obrani svojega prava na izdavačku djelatnost, pa i u području tiska, koja je svoje ispunjenje dočekala kad su se za to stvorile povoljne okolnosti, odnosno kad je i Katoličkoj crkvi i tadašnjoj Jugoslaviji, svakoj iz svojih razloga i motiva, bilo važno ponovno stupiti u dijalog. Dakako, i mi ćemo opisati razmjere te obnove te donijeti barem naslove i najvažnije podatke o pojedinim listovima koji su se u to vrijeme pojavili. Osim objavljene građe i literature, pritom ćemo posegnuti i za neobjavljenim arhivskim gradivom, ponajprije iz fonda Komisije za vjerska pitanja Izvršnoga vijeća Sabora Socijalističke Republike Hrvatske (dalje u tekstu: Komisija za vjerska pitanja ili Komisija), pohranjenog u Hrvatskom državnom arhivu, a manjim dijelom i gradivom Nadbiskupijskoga arhiva u Zagrebu te Arhiva (Pismohrane) Glasa Koncila da bismo dodatno rasvijetlili, ali i prvi put iznijeli neke aspekte teme koju obrađujemo i povijesnoga konteksta u kojoj se ona odvijala.

\section{Uspon i pad katoličkoga tiska tijekom prve polovine XX. stoljeća}

Početak 60-ih godina Katolička crkva u Hrvatskoj dočekala je praktički bez postojanja vlastitoga tiska, osobito onoga koji bi bio usmjeren široj čitalačkoj publici, odnosno vjernicima laicima, a ne samo kleru. Naime, nakon što je u prvim desetljećima XX. stoljeća, ponajprije kao rezultat djelovanja Hrvatskoga katoličkog pokreta, doživio nagli razvoj, katolički je tisak već u vrijeme Drugoga svjetskog rata, zbog ratnih prilika i gospodarske krize, znatno oslabljen, a nakon dolaska komunista na vlast 1945. gotovo je potpuno ukinut.

Svoj najveći procvat u povijesti - i brojem listova i glede njihove naklade - katolički je tisak u Hrvatskoj doživio između dva svjetska rata. Tako su uoči

2 AKMADŽA, Katolička crkva u komunističkoj Hrvatskoj, 301-302, 329, 436-438; MIKIĆ, AKMADŽA, „Kritike crkvenih i vjerničkih krugova na sadržaj Glasa Koncila od 1963. do 1972. godine”; MIKIĆ, „Sudski postupci protiv katoličkog tiska u komunističkoj Hrvatskoj 1960-ih i 1970-ih".

Usp. MATAUŠIĆ, „Prihvat Drugog vatikanskog koncila u Hrvatskoj na primjeru katoličkog tiska i odnosa Crkve prema medijima”; MATAUŠIĆ, „Katolički tisak u Zagrebačkoj nadbiskupiji”; MIKIĆ, „Crkveno i društveno značenje Glasa Koncila od 1963. do 1972.”; DUDA, „Prihvat II. Vatikanskog koncila u Hrvatskoj (II)”. 
početka Drugoga svjetskog rata Katolička crkva i katoličke organizacije imale više od 100 listova. ${ }^{4}$ Već u vrijeme Drugoga svjetskog rata od 1941. do 1945. dosta je katoličkih listova obustavilo izlaženje ili smanjilo nakladu. ${ }^{5}$ Završetkom rata 1945. prestaje izlaziti gotovo sav katolički tisak na hrvatskom jeziku jer je komunistička vlast sustavno i na različite načine - uskratom papira, konfiskacijom tiskarskih strojeva i zatvaranjem/oduzimanjem tiskara - onemogućila djelovanje katoličkih izdavača. U prvim poratnim mjesecima i godinama zbog takva su stanja predstavnici Katoličke crkve u više navrata prosvjedovali kod predstavnika vlasti. Primjerice, u svojoj predstavci od 21. srpnja 1945. zagrebački nadbiskup Alojzije Stepinac žali se predsjedniku tadašnje Vlade Federalne Hrvatske Vladimiru Bakariću: „Došli smo do stanja, da nas u štampi gotovo svakodnevno napadaju, a ne daju štampati nijednoga katoličkog lista." ${ }^{\prime \prime}$ Nezadovoljstvo Katoličke crkve odnosom novih vlasti prema katoličkom tisku najjasnije je izraženo u Pastirskome pismu Biskupske konferencije u rujnu 1945. godine:

„Katolička štampa je druga bolna točka u životu Katoličke crkve. Od nekih 100 časopisa, koliko smo ih imali prije rata, danas ni jedan ne izlazi. Kada je tražila dozvolu za izlaženje, navodili su se svi mogući razlozi, da se dozvola ne izda. Spominjala se i nestašica papira. A iz samog zagrebačkog Nadbiskupskog dvora odvezeno je nekoliko vagona papira, spremljena za katoličku štampu. Katoličke tiskare su većinom zatvorene i onemogućene. Zagrebačku Narodnu Tiskaru nastojalo se svim mogućim načinima onemogućiti. Kad nije išlo drukčije, onda se ravnatelja tiskare osudilo na gubitak nacionalne časti a tiskaru, koja nije njegovo vlasništvo, zaplijenilo. Tek prije nekoliko dana tiskara nam je na naš protest povraćena7. Velika tiskara Katoličkog tiskovnog društva u Ljubljani oduzeta je iz katoličkih ruku. Ista je sudbina zadesila katoličke tiskare u Mostaru, Šibeni$\mathrm{ku}$, Mariboru i Sarajevu. ${ }^{8}$ Tako se sistematski i po planu postupa s katoličkom štampom. A sloboda je katoličke štampe za Katoličku crkvu pitanje, o kojem ovisi dobro tolikih duša. Kako će se tim uvjetima moći razvijati katolička štampa, kad joj je oduzeta podloga, tiskare pa i papir?"9

4 U Pastirskom pismu iz rujna 1945. Biskupska konferencija navodi postojanje „nekih 100 časopisa, koliko smo ih imali prije rata", a u predstavci katoličkih biskupa Predsjedništvu Federativne Narodne Republike Jugoslavije sa sastanka u Ljubljani od 29. srpnja 1947. navodi se postojanje 137 predratnih listova na hrvatskom, slovenskom i jezicima nacionalnih manjina. Usp. AKMADŽA, Katolička crkva u komunističkoj Hrvatskoj, 100 (bilj. 407), 101.

5 Usp. MATAUŠIĆ, „Prihvat Drugog vatikanskog koncila u Hrvatskoj na primjeru katoličkog tiska i odnosa Crkve prema medijima”, 500; MATAUŠIĆ, „Katolički tisak u Zagrebačkoj nadbiskupiji”, 656.

6 KISIĆ-KOLANOVIĆ, „Pisma zagrebačkog nadbiskupa Alojzija Stepinca predsjedniku Narodne vlade Hrvatske Vladimiru Bakariću godine 1945.”, 147.

7 Nekoliko mjeseci poslije Narodna tiskara bit će ponovno konfiscirana. Vidi u: AKMADŽA, Oduzimanje imovine Katoličkoj crkvi, 133-137.

8 Nekoliko godina kasnije (1948.) i strojevi tiskare Đakovačke biskupije, koju je ustanovio još biskup J. J. Strossmayer, bit će konfiscirani i predani crnogorskoj vladi, koja ih je ustupila Novinsko-izdavačkom poduzeću „Pobjeda”. Usp. SRAKIĆ, „Urednici i suradnici Glasnikal Vjesnika Đakovačke i Srijemske biskupije od 1873. do 1997. godine”, 43.

9 NAZ, Ostavština Franje Kuharića, korice Spisi 1, Pastirsko pismo katoličkih biskupa Jugoslavije, izdano s općih Biskupskih Konferencija u Zagrebu, 20. 9. 1945., 3. 
Da je onemogućavanje vjerskoga tiska bilo sustavni dio partijske i državne politike svjedoči i zapisnik sa sjednice Politbiroa Centralnoga komiteta Saveza komunista Hrvatske od 27. prosinca 1946., na kojoj Vladimir Bakarić poručuje da vjerski tisak treba uništiti, a načelnik Odjeljenja zaštite naroda $\mathrm{za} \mathrm{Hr}$ vatsku Ivan Stevo Krajačić zaključuje da ako Agitprop (Odjeljenje za agitaciju i propagandu $)^{10}$ nije u stanju nadzirati vjerski tisak, onda treba postići da on uopće ne izlazi. ${ }^{11}$

Unatoč takvu stanju, u prvim poslijeratnim godinama ipak je bilo nekoliko pokušaja pokretanja katoličkih listova. Riječki svećenici pokušali su krajem 1945. pokrenuti svoj list, ali je već prvo izdanje zabranjeno zbog sadržaja. ${ }^{12}$ U Zagrebu je 1945. izašao list zagrebačkih župa Dobri pastir, a katoličke su organizacije pokušale pokrenuti i tjednike Nedjelja i Novi život, no te inicijative nisu zaživjele. ${ }^{13}$ Tijekom 1946. u Đakovu je umjesto privremeno obustavljenoga Glasnika Đakovačke biskupije izašlo 16 brojeva tjednika Istina. Posljednji je broj tiskan 12. svibnja 1946. ${ }^{14}$

No predstavnici Katoličke crkve nisu se mirili s takvim stanjem. Katolički tisak bio je česta tema brojnih predstavki predstavnicima vlasti, pa su se tako katolički biskupi sa svojega sastanka u Ljubljani krajem srpnja 1947. požalili Vladi Federativne Narodne Republike Jugoslavije i na stanje katoličkoga tiska:

„U čitavoj Jugoslaviji izlaze danas svega četiri vjerska lista za katolike: 1 mjesečnik, dva tjednika i 1 polumjesečnik. Jedan od njih izlazi u Beogradu, 2 u Sloveniji i 1 u Istri (Pazinu). Čitava Hrvatska zajedno s Dalmacijom, Bosna i Hercegovina pa i Bačka i Banat nemaju dakle ni jednog jedinog lista. To znači, da je nekoliko milijuna katoličkih vjernika potpuno lišeno blagodati vjerske štampe. Neka se ne kaže, da se nije ni pokušalo s izdavanjem vjerskih listova na području, gdje žive katolici, koji se u golemoj većini priznavaju Hrvatima. Pokušalo se, ali su ti pokušaji uvijek propali: katolički listovi morali su brzo prestati izlaziti. Našlo se je načina da ih se uguši. Tako jadno izgleda slika katoličke štampe u zemlji, gdje je prije rata izlazilo 75 listova na srpsko-hrvatskom jeziku, 52 lista na slovenskom jeziku i 10 listova na jezicima manjinskih narodnih skupina." ${ }^{\prime 5}$

10 Riječ je o tijelu Komunističke partije koje je, po uzoru na Sovjetski Savez, formirano još u Drugom svjetskom ratu, a djelovalo je u svrhu kontrole i usmjeravanja cjelokupnoga intelektualnog stvaralaštva u državi prema ideološko-političkim direktivama Centralnoga komiteta Komunističke partije Jugoslavije. Republički Agitprop reorganiziran je na prvoj poslijeratnoj sjednici Politbiroa Centralnoga komiteta Komunističke partije Hrvatske 1. lipnja 1945. ŠARIĆ, „Djelovanje Agitpropa prema književnom radu i izdavaštvu u NRH, 1945-1952.”, 389.

11 VOJNOVIĆ, Zapisnici Politbiroa Centralnoga komiteta Komunističke partije Hrvatske 1945. - 1952., sv. 1, 282-283.

12 AKMADŽA, Katolička crkva u komunističkoj Hrvatskoj, 101.

13 ZNIDARČIĆ, „Organizirano djelovanje katoličkih svjetovnjaka na području zagrebačke nadbiskupije (1852-1994)", 389-390.

14 ZOVKO, „Đakovačke tiskare i novine u razdoblju od 1853. do 1948. godine”, 48. Usp. i: NOVAK, Hrvatsko novinarstvo u 20. stoljeću, 463.

15 AKMADŽA, Katolička crkva u komunističkoj Hrvatskoj, 102. 
Jedini katolički list na hrvatskom jeziku namijenjen široj čitalačkoj publici, koji spominju i biskupi u navedenom pismu, u prvim poratnim godinama bio je tjednik Gore srca, koji je najprije u Trstu (od 1. travnja 1946.), potom u Rijeci (od 1. rujna 1946.) uređivao svećenik Božo Milanović (do 1948.), a izdavalo Književno društvo sv. Mohora za Istru. Početna mu je naklada bila 6000 primjeraka, no narasla je do $40.000 .{ }^{16}$ Ali i njegovi su pojedini brojevi bili zabranjivani. Primjerice, rješenjem javnoga tužitelja za Istru od 5. srpnja 1947. jedan je broj toga lista zabranjen, a kao razlozi se navode „članak 'Govor jednog ruskog nadbiskupa', te odvraćanje omladine od dobrovoljnog rada, prvenstveno nedjeljom, a zatim i to da list nikada ne donosi izvatke 'iz govora druga Tita i ostalih naših rukovodilaca, a Papinim reakcionarnim govorima i poslanicama posvećuje čitave stranice"' ${ }^{17} \mathrm{Da}$ bi list mogao nastaviti izlaziti, izdavanje je 1948. preuzelo Jeronimsko društvo u Zagrebu, koje je preimenovano u Hrvatsko književno društvo sv. Ćirila i Metoda, a uređivanje je preuzeo kanonik Pavao Lončar. ${ }^{18}$ I u idućim godinama list će se suočavati s problemima nedostatka papira i zabranom pojedinih brojeva (dva broja 1949. te jedan 1951.). List je naposljetku ugašen krajem 1952., kad mu je glavnim urednikom bio Franjo Grundler. ${ }^{19}$ Zadnji preostali katolički list na hrvatskom jeziku namijenjen široj čitalačkoj publici u Hrvatskoj ugašen je u vrijeme najveće poslijeratne krize u odnosima Jugoslavije i Svete Stolice, tijekom koje su razmijenjene oštre diplomatske note, a nakon odluke Svete Stolice da Alojzija Stepinca proglasi kardinalom prekinuti su i diplomatski odnosi. Inače, i u diplomatskoj noti koja je iz Vatikana upućena u Beograd 15. prosinca 1952. jugoslavenskim se vlastima, među ostalim, zamjera zabrana vjerskoga tiska i oduzimanje tiskara, te se kao preduvjet budućih odnosa navodi potreba poštovanja temeljnih prava Katoličke crkve, među kojima izrijekom i pravo na vlastiti tisak: „Katolici neće smjeti više biti stavljeni u okolnosti, koje će ih lišiti njihova tiska, koji će izlagati i tumačiti razne točke katoličkog nauka." ${ }^{20}$

Sljedećih desetak godina Katolička crkva u Hrvatskoj nije imala periodičkih publikacija za puk. Preživjela je tek beogradska Blagovest, katolički mjesečnik tiskan na ekavici. U Đakovu je izlazio službeni mjesečnik Vjesnik Đakovačke biskupije (koji ima neprekinutu povijest izlaženja od 1873., do 1945. bio je dvotjednik, a potom do 1948. pod imenima Obavijesti Biskupskog Ordinarijata i Okružnice izlazi tek povremeno). List je bio namijenjen svećenstvu, kao i Službeni vjesnik Zagrebačke nadbiskupije. Iznimka je ponovno bila jed-

16 NOVAK, Hrvatsko novinarstvo u 20. stoljeću, 463.

17 Isto, 464.

18 On je vjerojatno izabran među ostalim i zbog činjenice da je u vrijeme Nezavisne Države Hrvatske bio osuđen na smrt, pa se računalo na to da će kao žrtva ustaškoga režima ipak biti pošteđen pritisaka komunističkih vlasti. Usp. MATAUŠIĆ, „Prihvat Drugog vatikanskog koncila u Hrvatskoj na primjeru katoličkog tiska i odnosa Crkve prema medijima”, 500.

19 Povijest lista i okolnosti u kojima je djelovao u: MILIĆ, „Gore srca. Katolički tjedni list 1946-1953."

20 AKMADŽA, „Uzroci prekida diplomatskih odnosa između Vatikana i Jugoslavije 1952. godine”, 196. 
na katolička publikacija u Istri, Istarska Danica, katolički kalendar u izdanju Istarskoga književnog društva sv. Ćirila i Metoda u Pazinu, na čijem je čelu bio Božo Milanović, koja je izlazila od 1950. do 1954. godine. Vjernici su tako tijekom 50-ih godina mogli računati samo na godišnjake: Danicu, koju je u Zagrebu izdavalo Hrvatsko književno društvo sv. Ćirila i Metoda, i Dobroga pastira u izdanju režimu bliskoga Udruženja katoličkih svećenika Narodne Republike Bosne i Hercegovine u Sarajevu. ${ }^{21}$

\section{Normalizacija crkveno-državnih odnosa kao preduvjet i kontekst obnove katoličkoga tiska}

Za fenomen obnove katoličkoga tiska u Hrvatskoj 60-ih godina svakako je važan i društveno-politički kontekst toga vremena. Naime, već od kraja 50-ih, a osobito tijekom 60-ih, u sklopu Saveza komunista, posebno u Sloveniji i Hrvatskoj, jačaju tzv. reformske snage, koje se zalažu za djelomičnu decentralizaciju, protive državnom unitarizmu i forsiranju tzv. jugoslavenske kulture, što će uz ostalo rezultirati i izglasavanjem novoga jugoslavenskog Ustava 1963. godine. ${ }^{22}$ Te su društveno-političke promjene dovele i do stanovite liberalizacije tadašnjih medija u Hrvatskoj ${ }^{23}$, što je u zakonskom smislu bilo vidljivo i u donošenju novoga zakona o tisku 31. listopada 1960. godine. ${ }^{24} \mathrm{U}$ njemu je bilo određeno da svi građani imaju pravo izdavati novine i druge oblike tiska te osnivati i upravljati ustanovama i organizacijama za objavljivanje i širenje informacija. ${ }^{25}$

No mi ćemo se u ovome radu fokusirati na poboljšanje državno-crkvenih odnosa u Hrvatskoj i tadašnjoj Jugoslaviji kao najvažniji preduvjet i razlog obnove katoličkoga tiska i izdavačke djelatnosti Crkve uopće u tadašnjoj Hrvatskoj.

Ponajprije se krajem 50-ih počela mijenjati klima u odnosima između Katoličke crkve i zemalja tzv. istočnoga bloka. U listopadu 1958. u Vatikanu umire papa Pio XII. (1939. - 1958.), a 28. listopada za novoga papu izabran

${ }^{21}$ MATAUŠIĆ, „Prihvat Drugog vatikanskog koncila u Hrvatskoj na primjeru katoličkog tiska i odnosa Crkve prema medijima”, 500-501. Usp. i: MATAUŠIĆ, „Katolički tisak u Zagrebačkoj nadbiskupiji”, 656-657.

22 RADELIĆ, Hrvatska u Jugoslaviji, 360-361.

23 MIHALJEVIĆ, „Liberalizacija i razvoj medija u komunističkoj Hrvatskoj 1960-ih i na početku 1970-ih", 239-258.

24 „Zakon o štampi i drugim oblicima informacija”, Službeni list Federativne Narodne Republike Jugoslavije (Beograd), 45 (1960).

25 NOVAK, Hrvatsko novinarstvo u 20. stoljeću, 597. I tadašnji glavni urednik Glasa Koncila Vladimir Pavlinić ističe važnost toga zakona: „Novo se razdoblje relativne slobode štampe u Jugoslaviji otvorilo s novim Zakonom o štampi i drugim sredstvima informacije, izdanom 1960. godine. Ni prethodnim Zakonom o štampi nije sve to bilo zabranjeno, ali novim Zakonom bilo je izričito dopušteno.” Usp. PAVLINIĆ, „Katolička štampa u Hrvatskoj”, 66; MIKIĆ, „Sudski postupci protiv katoličkog tiska u komunističkoj Hrvatskoj 1960-ih i 1970-ih”, 183184 . 
je Angelo Giuseppe Roncalli - Ivan XXIII. U njegovu je relativno kratkome mandatu (umro je 3. lipnja 1963.) došlo do znatnih promjena u životu Katoličke crkve, osobito u njezinu otvaranju prema svijetu i započinjanju dijaloga s drugima, pa i ateistima i ateističkim režimima u svijetu, što će osobito doći do izražaja održavanjem Drugoga vatikanskoga koncila (1962. - 1965.), ali i u enciklici Pacem in terris (Mir na zemlji) od 11. travnja 1963., u jeku tzv. Kubanske krize. Za vrijeme njegova pontifikata Sveta Stolica imala je i široku diplomatsku inicijativu uspostave diplomatskih odnosa sa zemljama srednje i istočne Europe, uključujući i Savez Sovjetskih Socijalističkih Republika, poznatu kao vatikanska istočna politika - Ostpolitik, da bi se olakšao položaj katoličkih vjernika u tim zemljama s komunističkim režimima.

U Hrvatskoj pak 10. veljače 1960. u kućnom pritvoru u župnom uredu u Krašiću umire kardinal Alojzije Stepinac. Već i pri odlučivanju o mjestu njegova ukopa državne su vlasti predstavnicima Katoličke crkve u Hrvatskoj poslale signal da su spremne na početak normalizacije odnosa. Naime, početni stav da Stepinac, kao zatvorenik, treba biti pokopan u mjestu u kojem je izdržavao kaznu, dakle Krašiću, vlasti su 12. veljače promijenile dopustivši da ipak bude pokopan u zagrebačkoj katedrali, kao i njegovi prethodnici, o čemu je tadašnjega nadbiskupa, koadjutora Franju Šepera, osobno izvijestio predsjednik Republičke komisije za vjerska pitanja Stjepan Iveković, uz poruku kako se nada da će nadbiskup to shvatiti kao dobru želju vlasti za uspostavljanjem normalnih odnosa s Katoličkom crkvom. ${ }^{26}$

Iste se godine i sa strane Crkve u Hrvatskoj i sa strane državnih vlasti počinju pojavljivati signali da je sazrelo vrijeme za poboljšanje odnosa. Primjerice, na sjednici Savezne komisije za vjerska pitanja 26. veljače 1960. konstatirana je sve veća spremnost biskupa za kontakte s vlastima, kao i želja Svete Stolice za normalizacijom odnosa, te je upozoreno na tri temeljna pitanja koja će se morati rješavati u odnosima s Crkvom: katehizacija, vjerski tisak i staleška udruženja katoličkih svećenika. ${ }^{27}$

Da se vlasti pripremaju na obnovu kontakata s predstavnicima Katoličke crkve, uključujući i Svetu Stolicu, pokazuju i upute koje je u tom smislu svim veleposlanstvima u svijetu 12. ožujka 1960. uputio Savezni sekretarijat za inozemne poslove:

„U posljednje vrijeme uočavaju se znaci da se Vatikan nastoji prilagoditi novonastaloj situaciji popuštanja u odnosima Istok-zapad, jer ocjenjuju da nekompromisnim stavovima slabe svoju ulogu i značaj pa i u strogo katoličkim zemljama Zapada, a posebno u katoličkim zemljama lagera. Ova tendencija odražava se i u odnosu na našu zemlju. [...] Smatramo, da će smrt Stepinca omogućiti tolerantniji odnos države i Crkve." ${ }^{28}$

26 ANCIĆ, „Pregovori i ponovna uspostava diplomatskih odnosa između Vatikana i SFRJ”, 24.

27 Isto, 25.

28 RADIĆ, Država i verske zajednice, 454-455. 
U srpnju 1960. Savezna komisija za vjerska pitanja izradila je i opsežan elaborat pod naslovom „Odnosi Vatikan - Jugoslavija” u kojem su, među ostalim, navedena traženja koja bi Jugoslavija postavila u eventualnim razgovorima te se procjenjuju i moguće teme koje bi Katolička crkva u Jugoslaviji i Sveta Stolica mogle postaviti kao uvjet za sređivanje odnosa. Na kraju elaborata stoji da od svih otvorenih pitanja Katolička crkva pokazuje najviše interesa za slobodu katehizacije, tisak i izdavačku djelatnost te vjerske škole. ${ }^{29}$

I u analizi Savezne komisije za vjerska pitanja iz 1960. ističe se da će Katolička crkva, na temelju svih dostupnih informacija, u očekivanim pregovorima od države zahtijevati slobodu publicističke izdavačke djelatnosti:

\begin{abstract}
„Misli se na izdavanje publikacija i verske literature bez ograničenja, ali se u prvom redu radi o izdavanju dnevnih i nedeljnih listova i časopisa, namjenjenih široj publici, a koji ne bi imali isključivo verski karakter već bi se bavili i političkim i društveno-javnim pitanjima. Sa ovim listovima i časopisima se misli uticati na građane kako u političkom tako i po društvenim pitanjima. Pitanje izdavanja verske štampe i literature je regulisano Zakonom o pravnom položaju verskih zajednica i drugim propisima. Koristeći to RKC godišnje štampa ogromne količine verskih materijala i manje-više ovim putem podmiruju svoje verske potrebe. Izdavanje je u porastu. U poslednje vrijeme sve se ređe čine smetnje (a i te treba izbjegavati ako nisu u pitanju stvarno posebni razlozi) izdavanju verske štampe i literature ukoliko se to ne kosi sa pozitivnim zakonskim propisima. Što se tiče navedenih dnevnika, nedeljnih listova ili časopisa izdavanje istih ne bi trebalo dozvoliti." ${ }^{30}$
\end{abstract}

Istodobno je i Sveta Stolica počela s pripremama za moguću obnovu službenih kontakata s Jugoslavijom te je u srpnju 1960. na sjednici Kardinalske komisije za inozemne poslove bilo riječi i o tom pitanju, o čemu je informirana i Biskupska konferencija Jugoslavije ${ }^{31}$, nakon čega su se biskupi sa svojega jesenskog zasjedanja vlastima obratili predstavkom od 3. listopada 1960. U njoj su izrazili spremnost na razgovore o normalizaciji odnosa između Crkve i države, uz napomenu da je najvažniji sugovornik s crkvene strane i dalje Sveta Stolica, odnosno papa. U svojem pismu biskupi su istodobno upozorili i na niz poteškoća s kojima se suočavaju Crkva i njezini vjernici, među kojima je navedeno i pitanje katoličkoga tiska. ${ }^{32}$

U isto vrijeme Komisija za vjerska pitanja u svojem izvješću o radu u 1963. uočava kako se promjene koje na Drugom vatikanskom koncilu doživljava Katolička crkva, osobito u smislu dijaloga sa svijetom i promicanja mira u svijetu, odražavaju i na držanje katoličkoga klera u Hrvatskoj i njihov sve pomirljiviji stav prema „našoj društvenoj stvarnosti”, pa zaključuje:

29 ANCIĆ, „Pregovori i ponovna uspostava diplomatskih odnosa između Vatikana i SFRJ”, 31.

30 HR-HDA-310-KOVZ, Pov. 58-1/1960, „Rimokatolička vjerska zajednica - odnosi - informacije", 26. 4. 1960., 2.

31 RADIĆ, Država i verske zajednice, 456.

32 HR-HDA-310-KOVZ, kut. 41, br. 08-130-1/1960, Pismo Predsjedništva Biskupske konferencije SIV-u FNRJ br. 96-BK-60, 23. 9. 1960. 
„Ovako evidentna izmjena Katoličke crkve u odnosima s državom nužno nameće potrebu da i mi preispitamo svoju taktiku u odnosu na Crkvu jer se ona u sadašnjoj situaciji nužno mora mijenjati." ${ }^{33}$

Višegodišnja nastojanja u normalizaciji odnosa između Katoličke crkve i jugoslavenskih vlasti napokon su 25. lipnja 1966. rezultirala potpisivanjem Protokola o razgovorima koji su vođeni izmedu predstavnika vlade Socijalističke Federativne Republike Jugoslavije i predstavnika Svete Stolice, nakon čega je Sveta Stolica za svojega izaslanika pri Vladi Socijalističke Federativne Republike Jugoslavije imenovala mons. Marija Cagnu, a Jugoslavija je u Vatikan poslala Vjekoslava Cvrlju.

Premda su predstavnici Crkve u Hrvatskoj potpisivanje Protokola primili s primjetnom dozom rezerviranosti, nakon toga događaja, osobito zbog utjecaja Drugoga vatikanskoga koncila i koncilske obnove, uslijedila je primjetna pojačana aktivnost Crkve na mnogim područjima. Da su tu pojačanu aktivnost Katoličke crkve uočavali i predstavnici vlasti - osobito u jačanju vjerskoga odgoja i mladih te izdavačkoj djelatnosti - vidi se i iz pojedinih analiza koje su za potrebe raznih tijela vlasti pripremane u Komisiji za vjerska pitanja. ${ }^{34}$

Što se pak tiče službenih odnosa Svete Stolice i Jugoslavije, oni su vrhunac $\mathrm{u}$ to vrijeme doživjeli uspostavom punih diplomatskih odnosa 14. kolovoza 1970., a već 1971. predsjednik Jugoslavije Josip Broz Tito službeno je posjetio Vatikan i susreo se s papom Pavlom VI.

Od početka 60-ih godina, dakle, u kontekstu postupne normalizacije odnosa između Katoličke crkve, i one u Hrvatskoj i Jugoslaviji i na razini Svete Stolice, s jugoslavenskim vlastima, otvorila se mogućnost za ponovno pokretanje katoličkoga tiska, koji je Crkvi očito bio važan za unaprjeđenje njezina javnoga djelovanja, te nije propuštala priliku na to upozoriti i tadašnje vlasti. Državnim je vlastima pak bilo važno koliko-toliko normalizirati odnose s Katoličkom crkvom, ali i diplomatske odnose sa Svetom Stolicom, te su odlučile, kako smo naveli citirajući pojedine izvore, „preispitati svoju taktiku” prema Crkvi i „izbjegavati smetnje" djelovanju katoličkoga tiska, osim kad on, po procjeni vlasti, bude zalazio u društveno i političko područje. Tim više što je i taj obnovljeni tisak u velikoj mjeri odražavao promjene do kojih je u Crkvi tih godina dolazilo pod utjecajem Drugoga vatikanskoga koncila, pa je komunistička vlast, kako zaključuje i povjesničar Ivo Banac, tom obnovljenom katoličkom tisku „odlučila dati propusnicu” ili, riječima tadašnjega novinara u Glasu Koncila Živka Kustića, vlast je „nekako shvatila da se ne isplati ili da se ne može katoličku zajednicu držati sasvim stegnutu na području javnog informiranja”. ${ }^{35}$

33 HR-HDA-310-KOVZ, Zapisnici sa sjednica Komisije 1964. (Knjiga 6), Zapisnik sa sjednice Komisije za vjerska pitanja NRH, 1. i 8. 2. 1964., Prilog izvještaju o radu Komisije za vjerska pitanja Izvršnog vijeća Sabora SR Hrvatske za 1963. godinu, 27.

34 Usp. HR-HDA-310-KOVZ, kut. 70, Pov. br. 222/1-1966, Neke karakteristike odnosa s Katoličkom crkvom.

35 BANAC, Hrvati i Crkva, 117. 
I same su komunističke vlasti zaključile da mogu imati i koristi od promjena koje je u život Crkve donosio Drugi vatikanski koncil, kako zbog njegove dijaloške usmjerenosti tako i zbog podjela koje bi on mogao unijeti u redove Crkve, te su, „zadovoljni razvojem stanja na Koncilu, smatrali [su] da treba omogućiti pojačano informiranje svećenstva i javnosti o Koncilu”, pa i preko crkvenoga tiska. ${ }^{36}$

\section{Obnovljeni katolički tisak}

Početkom 60-ih godina katolički su listovi osnivani dosta oprezno, njihov se sadržaj ograničavao na vjerske teme, a objavljene vijesti i izvješća uglavnom su se odnosili na Crkvu izvan Hrvatske i tadašnje Jugoslavije. I Komisija za vjerska pitanja u to je vrijeme stekla dojam da su „vjerske zajednice, a posebno rimokatolička, u prethodnoj godini ispitivale situaciju i ocijenivši je povoljnom, počele sa sve većim zahtjevima za štampanje vjerske literature" ${ }^{37}$

Među prvima od onih koji su iskoristili nove okolnosti i počeli s izlaženjem bila je Služba Božja, liturgijsko-pastoralni list koji je od 1. studenog 1960. izdavao Interdijecezanski liturgijski odbor, a uređivao Jure Radić, profesor na Franjevačkoj visokoj bogosloviji u Makarskoj. Uvodnik prvoga broja napisao je zagrebački nadbiskup Franjo Šeper, koji je bio i predsjednik Odbora. Prvo godište umnažano je ciklostilom, a od 1962. tiska se u tiskari u zgradi Đakovačke biskupije. Poslije će izdavanje lista preuzeti Franjevačka visoka bogoslovija Makarska-Dubrovnik. I taj je list bio prije svega namijenjen svećenicima i redovnicima. Početna naklada nije nam poznata, a za 1962. godinu Komisija za vjerska pitanja navodi da je tiskan u 3100 primjeraka. ${ }^{38}$

Prvi list koji se po formi i sadržaju počeo obraćati i „običnim” vjernicima bio je mjesečnik Glasnik sv. Antuna Padovanskoga, koji se pojavio u travnju 1962. godine. Izdavala ga je u Zagrebu Provincija franjevaca konventualaca, a prvi mu je glavni urednik bio Ivon Ćuk (najčešće je pisao pod pseudonimom Yves Ivonides). Od 1968. mijenja naziv u Veritas, koji je zadržao do danas. List se tiskao u „Tipografiji” u Đakovu. Po sadržaju je spadao u pučke listove i dijelom je bio nastavak lista Svetište sv. Antuna, koji je 1929. pokrenuo fra Ambroz Vlahov, odnosno svojevrsni nastavak predratne izdavačke tradicije te redovničke zajednice u Hrvatskoj. Prvi broj obnovljenoga Glasnika izašao je u nakladi od 4000 primjeraka, već nakon dvije godine ona je dosegnula prosjek od 33.000 po broju, a vrhunac 1966. s oko 40.000 tiskanih primjeraka po broju. Krajem 60-ih godina naklada je počela padati, a sredinom 70-ih ustalila se na oko 20.000 primjeraka. ${ }^{39}$

36 AKMADŽA, Katolička crkva u komunističkoj Hrvatskoj, 266.

37 HR-HDA-310-KOVZ, Zapisnici sa sjednica Komisije za vjerska pitanja 1963., Zapisnik sa sjednice Komisije od 4. 3. 1963., 47-48.

38 Isto, 40-42.

39 „Povijest Veritasa”. 
Početkom 1963. franjevci u Splitu počinju objavljivati list Marija, koji je u početku izlazio kao dvomjesečnik, a poslije (od 1966.) u osam odnosno (od 1968.) u deset primjeraka godišnje. Uređivao ga je fra Vjenceslav Glibotić, a glavni mu je cilj bio promocija marijanske pobožnosti, s obzirom na činjenicu da su i glavni samostani franjevačke splitske provincije bili vezani uz marijanska svetišta - Gospa Sinjska, Gospa od Zdravlja u Splitu te Gospa Lurdska u Zagrebu. ${ }^{40}$ Početna naklada bila je 7000 primjeraka, a do početka 70 -ih se udvostručila. ${ }^{41}$ Tiskan je u tiskari „Slobodne Dalmacije”. Većina prvih autora i suradnika bili su profesori franjevačke gimnazije u Sinju.

Isusovci u Zagrebu u listopadu 1963. obnavljaju izdavanje časopisa Glasnik Srca Isusova i Marijina ${ }^{42}$, nastavljajući se na tradiciju predratnoga lista Glasnik Srca Isusova, koji je 1892. osnovao sarajevski nadbiskup Josip Stadler. ${ }^{43}$ Početna mu je naklada bila 25.000 primjeraka ${ }^{44}$, a do sredine 60 -ih narasla je na više od $40.000^{45}$. Glavni mu je urednik bio Franjo Šipušić.

Prve prave poslijeratne katoličke novine Crkva u Hrvatskoj dobit će tek pokretanjem Glasa (s) Koncila 1962./1963. godine. Kako je riječ o najvažnijem i najutjecajnijem katoličkom listu, u nastavku rada posvetit ćemo mu zasebno poglavlje, a prije toga donosimo informacije o još nekim pokrenutim/obnovljenim izdanjima Katoličke crkve iz 60 -ih godina.

I teološka učilišta u to vrijeme pokreću svoje specijalizirane teološke časopise: Katolički bogoslovni fakultet u Zagrebu Bogoslovsku smotru (1963.), Visoka bogoslovna škola u Splitu Crkvu u svijetu (1966.), Franjevačka visoka bogoslovija u Makarskoj zbornik Kačić (1967.), a od početka 70-ih i Filozofsko-teološki institut Družbe Isusove u Zagrebu obnavlja izdavanje svojega časopisa Obnovljeni život (1971.), koji je pod imenom Život izlazio od 1919. do 1945. godine.

Od druge polovine 60 -ih godina pojavljuje se i nekoliko publikacija namijenjenih različitoj vrsti publike u izdanju novoutemeljenoga Centra za koncilska istraživanja, dokumentaciju i istraživanje „Kršćanska sadašnjost” (KS), koji će postati najvažnijom izdavačkom ustanovom Katoličke crkve za tiskanje stručne teološke literature. Od kraja 60-ih Kršćanska sadašnjost objavljivala je i više važnih listova i časopisa: teološki časopis Svesci (od 1966./1967. nakladnik mu je Hrvatsko književno društvo sv. Ćirila i Metoda, a od 1969. Kršćanska sadašnjost), koji je uređivao Tomislav Šagi-Bunić; Svjedočenje građa i pogledi u Zagrebu (1968.) pod uredništvom Vjekoslava Bajsića; Upo-

40 MATAUŠIĆ, „Prihvat Drugog vatikanskog koncila u Hrvatskoj na primjeru katoličkog tiska i odnosa Crkve prema medijima”, 506.

${ }^{41}$ „Franjevci Split, kratka povijest”.

42 List nije izlazio od prosinca 1945., nakon što su njegovu izdavaču konfiscirani tiskara i zalihe papira. MATAUŠIĆ, „Prihvat Drugog vatikanskog koncila u Hrvatskoj na primjeru katoličkog tiska i odnosa Crkve prema medijima”, 506, bilj. 21.

43 "Povijest Glasnika Srca Isusova i Marijina”.

44 MATAUŠIĆ, „Prihvat Drugog vatikanskog koncila u Hrvatskoj na primjeru katoličkog tiska i odnosa Crkve prema medijima", 506.

45 NOVAK, Hrvatsko novinarstvo u 20. stoljeću, 597. 
znajmo Bibliju (časopis pokrenut u listopadu 1966. u nakladi Nadbiskupskoga bogoslovnog sjemeništa pod uredništvom Romilda Lovrića, od kraja te godine preuzimaju ga salezijanci, a od broja 8/1968. prelazi u nakladu Kršćanske sadašnjosti, a uređuje ga fra Bonaventura Duda); Služba riječi u Zadru (1969.), koju je uređivao Marijan Grgić; bilten Poslušni Duhu (1966., u izdanju Glasa Koncila), čiji je urednik bio Tomislav Šagi-Bunić; Effata (1969.), koju su uređivale redovnice, najprije Teofila Funes, potom Mariangela Žigrić, a od početka 70-ih izlazi i AKSA - aktualnosti Kršćanske sadašnjosti (1970.), pod uredništvom Stjepana Trpimira Grgmeca, te mjesečna obiteljska revija Kana (1970.), čiji je prvi glavni urednik bio Vladimir Pavlinić. ${ }^{46}$ Kršćanska sadašnjost kasnije će, tijekom 70-ih, pokrenuti još neke listove i časopise, ali i stvarati dokumentarne filmove i gramofonske ploče, no kako to i temom i razdobljem izlazi iz okvira ovoga rada, dalje to ovdje nećemo obrađivati.

Godine 1968. Hrvatsko književno društvo sv. Ćirila i Metoda (danas sv. Jeronima) pokreće književnu reviju Marulić, najprije kao zbornik, a od 1969. kao dvomjesečni časopis za književnost i kulturu.

Od početka 60-ih pojavljuju se i brojna lokalna crkvena izdanja, odnosno župski listovi i časopisi. Ujesen 1963. u Bakru počinju izlaziti Bakarska zvona, župni list župe Bakar, a uređivao ih je mons. Josip Šojat. ${ }^{47}$ Suradnik mu je bio, a kasnije i urednik, mons. Anton Sironić. Ubrzo je list izrastao u mjesečnik tadašnje Riječko-senjske nadbiskupije te 1971. promijenio ime u Zvona. ${ }^{48}$

Po podacima kojima je raspolagala Komisija za vjerska pitanja, od važnijih župskih listova 1962. pokrenuti su Ministrant u Slavonskom Brodu, Naša župa u Velikoj Kopanici kod Slavonskoga Broda i Poruke župljanima u Osijeku te Vjesnik bl. Nikole Tavelića u Šibeniku (pokrenuo ga je 1961. fra Ante Crnica). ${ }^{49}$ Iduće godine Komisija registrira i pokretanje listova Naša župa u Zatonu kod Šibenika, Poruka s križa u Sisku, ali i Dođi kraljevstvo Tvoje, list bogoslova Katoličkoga bogoslovnog fakulteta u Zagrebu, Katehist, koji je izdavao Katehetski institut u Zagrebu, te Molite braćo u nakladi Interdijecezanskoga liturgijskog odbora..$^{50}$

I 1967. još se uvijek osnivaju i Komisija registrira nove župne listove, npr. Svjetionik župe Bast - Baška Voda ${ }^{51}$, Župa Kraljice sv. Krunice u Zagrebu ${ }^{52}$, Duh zajedništva župe sv. Mihaela u zagrebačkoj Dubravi, za koji se navodi

46 CIFRAK, „Izdavačka djelatnost Kršćanske sadašnjosti kao vrijeme teologije”, 54-56; BAGARIĆ, „Informativna sredstva Kršćanske sadašnjosti”, 308-325; NOVAK, Hrvatsko novinarstvo u 20. stoljeću, 598.

47 DEVČIĆ, „Mons. dr. Josip Šojat (1912. - 1996.)”, 406.

48 "Zvona' proslavila zlatni jubilej”.

49 HR-HDA-310-KOVZ, Zapisnici sa sjednica Komisije za vjerska pitanja (Knjiga 5), Zapisnik sa sjednice Komisije, 4. 3. 1963., 40-42.

50 HR-HDA-310-KOVZ, Zapisnici sa sjednica Komisije za vjerska pitanja (Knjiga 6), Prilog sjednici Komisije za vjerska pitanja od 1. i 8. 2. 1964., 5-6.

51 HR-HDA-310-KOVZ, kut. 72, Pov. br. 52/1967, Mjesečna informacija o aktivnosti i pisanju vjerske štampe, god. IV, br. 1, 6 .

52 Isto, 8. 
da je to „prvi vjerski list koji uređuju župljani” ${ }^{53}$, ali i Vijesti župe sv. Antuna Padovanskog ${ }^{54}, \mathrm{Na}$ vidiku Janjine župe Janjina na Pelješcu ${ }^{55}$, Idite k Josipu župe sv. Josipa u Zagrebu ${ }^{56}$, Kairos župe u Samoboru, koji se umnožavao u franjevačkom samostanu u Zagrebu ${ }^{57}$, Marijin Vjesnik svetišta Gospe Trsatske u Rijeci $^{58}$, Svijetli akordi u Sisku te Mladi prijatelji u Sv. Lovreču u Istri. ${ }^{59}$

Možemo zaključiti da se 60-ih godina diljem Hrvatske javljalo sve više i više župnih listova, od kojih državne vlasti mnoge zasigurno nisu ni uočile jer su uglavnom umnažani ciklostilom i distribuirani samo u crkvama pojedinih župa, pa uopće nisu prijavljivani predstavnicima vlasti.

Što se tiče naklada pojedinih župskih listova, one su iznosile od nekoliko stotina do nekoliko tisuća primjeraka po broju. Prenoseći podatke o nakladi pojedinih listova za 1967. koje je objavilo glasilo Saveza novinara Jugoslavije, Božidar Novak spominje župski tromjesečnik iz Slavonskoga Broda Ministrant (naklada 7000 primjeraka), mjesečnik Naša župa iz Karlovca (naklada 2000 primjeraka), dvomjesečnik Lanterna sv. Marka iz Korčule (naklada 1000 primjeraka) te povremeni list Naš zavjet iz Makarske (naklada 800 primjeraka). ${ }^{60}$

\section{Glas Koncila kao najvažniji crkveni izdavački pothvat}

Sažimajući svjedočanstva svjedoka vremena i aktera pokretanja najvažnijih poslijeratnih crkvenih novina Glasa (s) Koncila, mogli bismo zaključiti da je taj list, ali i neki drugi izdavački projekti, nastao kao rezultat djelatnosti i nastojanja dvaju intelektualnih i vjerničkih krugova: 1. mladih zagrebačkih teologa koji će nešto kasnije (uglavnom) djelovati u okviru Kršćanske sadašnjosti i 2. ostataka starijih krugova „predratnih” vjernika laika, čija je djelatnost u crkvenom tisku i aktivnom vjerničko-društvenom životu bila prekinuta dolaskom komunizma na vlast 1945., ali su i dalje posjedovali znanja i vještine stvaranja i uređivanja listova. ${ }^{61}$

Što se tiče prvoga kruga, on je nastajao već od početka 60-ih na temelju poticaja koji je unutarcrkvenom životu dalo pripremanje i održavanje Drugoga vatikanskoga koncila i provođenje (post)koncilske obnove Crkve. U tim je okolnostima stvoren i, u početku neformalan, teološki intelektualni krug koji će poslije „iznjedriti” i po svojoj plodonosnosti najvažniju poslijekoncilsku

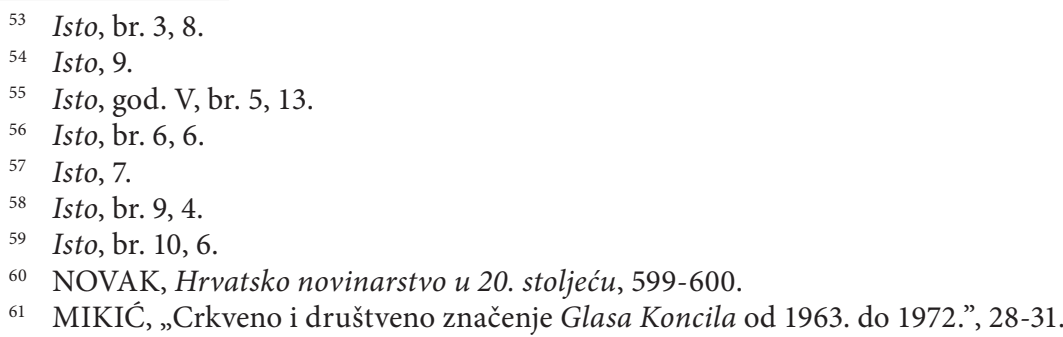


crkvenu instituciju u Hrvatskoj - Kršćansku sadašnjost. ${ }^{62}$ Sadašnji sisački biskup Vlado Košić u jednom je izlaganju sudionike toga intelektualnoga kruga nazvao „zagrebačka teološka škola”63, ubrojivši u njega Tomislava Šagi-Bunića, Vjekoslava Bajsića, Josipa Turčinovića, Bonaventuru Dudu, Ivana Goluba, Marijana Valkovića, Jerka Fućaka, Adalberta Rebića, Aldu Starića... I Josip Turčinović, jedan od pokretača Kršćanske sadašnjosti, svjedoči da „isti ljudi koji su pokrenuli KS sudjelovali su naime u svim onim inicijativama koje je bio pobudio Koncil, a među njima je bila jedna od najznačajnijih upravo oživjeli tisak i formiranje nove generacije teologa" ${ }^{64}$

Osim spomenutih svećenika i teologa, u novim inicijativama, pa tako i u pokretanju Glasa (s) Koncila, sudjelovali su i katolički intelektualci-laici. Jedan od njih, Lav Znidarčić, dapače tvrdi, pozivajući se pritom na svoje dnevničke zapise, da je „katolički dvotjednik (kasnije tjednik) pokrenut [je] na inicijativu katoličkih svjetovnjaka iz Zagreba" ${ }^{65}$ Još jedan istaknuti laik toga vremena, odvjetnik Sibe Zaninović, u jednome pismu uredništvu - koje u svojem pismu suradnici lista Smiljani Rendić od 25. rujna 1972. citira glavni urednik Glasa Koncila Vladimir Pavlinić - tvrdi da „pokretači vjerskog lista u nas nisu bili samo svećenici, nego u istoj mjeri i laici". ${ }^{66}$ Potvrđuje to i Bonaventura Duda kad navodi da se ideja o pokretanju katoličkoga lista pojavila „u više spontanih i organiziranih razgovora mlađih zagrebačkih svećenika i istaknutijih laika, osobito za vrijeme tadanjih tečajeva za svećenike" te da su se spomenuti laici i svećenici povremeno okupljali u prostorijama Hrvatskoga književnog društva sv. Ćirila i Metoda. ${ }^{67}$ Osim prvoga urednika lista Zorislava Lajoša, Duda kao sudionike tih okupljanja spominje katoličke laike Luku Perinića, Velimira Deželića, Sibu Zaninovića, Milostislava Ciku i druge. I dugogodišnji urednik Glasa Koncila Živko Kustić svjedoči da su katolički laici, od kojih su mnogi djelovali i u predratnim katoličkim organizacijama i listovima, neprestano poticali biskupe: „Treba početi s novinama, bez novina se ne može, postoje i neke šanse..."68

Što se tiče same realizacije osnutka lista, neposredno su ga potaknuli početkom listopada 1962., u povodu početka zasjedanja Drugoga vatikanskoga koncila, fra Bonaventura Duda, Tomislav Šagi-Bunić i fra Zorislav Lajoš,

62 Centar za koncilska istraživanja, dokumentaciju i informacije „Kršćanska sadašnjost” formalno je utemeljio zagrebački nadbiskup kardinal Franjo Šeper 22. veljače 1968., a na prijedlog teologa Josipa Turčinovića, Tomislava Šagi-Bunića i Vjekoslava Bajsića. No krug teologa koji ga je činio djelovao je i prije, pa se tako za Božić 1966. pojavio časopis Svesci - Kršćanska sadašnjost.

63 KOŠIĆ, „Recepcija Koncila u Hrvatskoj - uloga Kršćanske sadašnjosti u tome”, 23.

${ }^{64}$ TURČINOVIĆ, „Kršćanska sadašnjost u pokoncilskoj obnovi”, 153. Ovdje cit. prema: TURČINOVIĆ, Misao vjere, 147.

65 ZNIDARČIĆ, „Organizirano djelovanje katoličkih svjetovnjaka na području zagrebačke nadbiskupije (1852-1994)", 390.

66 Osobni arhiv Vladimira Pavlinića, Pismo Vladimira Pavlinića Smiljani Rendić, 25. 9. 1972.

67 DUDA, „Prihvat II. Vatikanskog koncila u Hrvatskoj (II)”, 257-258.

68 Živko KUSTIĆ, „Glas Koncila u pokoncilskom vremenu”, 122. Usp. i: Živko KUSTIĆ, „U matičnom tijeku hrvatskoga katolištva”, Glas Koncila (Zagreb), 8. 8. 1993., 5. 
a odobrio nadbiskup Franjo Šeper neposredno pred odlazak na zasjedanje Koncila $^{69}$, te je do kraja godine tehnikom ciklostila objavljeno 11 primjeraka tjednika Glas s Koncila. Impresum prvoga broja kao odgovornoga urednika navodi kancelara Nadbiskupskoga duhovnog stola Dragutina Hrena, a (u impresumu nenavedeni) organizator i glavni urednik bio je fra Zorislav Lajoš iz franjevačkoga samostana na zagrebačkom Kaptolu. Osim njega tekstove (uglavnom vijesti i izvješća o tijeku zasjedanja Koncila) pisali su i fra Bonaventura Duda, isusovac Mijo Škvorc i drugi suradnici, a svojim iskustvom u pripremi tiska i izlaženju biltena, ali i kasnijega lista, znatno je doprinio i Luka Perinić iz Hrvatskoga književnog društva sv. Ćirila i Metoda. Za prvi broj Glasa s Koncila fra Mirko Mataušić navodi da je umnožen u 6000 primjeraka $^{70}$, a fra Bonaventura Duda piše da je načinjeno 12.000 primjeraka. $^{71}$ U samom Glasu Koncila također navode potonju brojku: „Naklada 4.000; naknadna potražnja odmah je povisila nakladu na 12.000 primjeraka."72 Do 11. broja naklada je dosegnula 25.000 primjeraka. Kako je taj posao premašivao mogućnosti kaptolskih franjevaca, u umnažanju lista pomagale su i druge redovničke zajednice: sestre Naše Gospe, trećoredci, isusovci. ${ }^{73}$ Bilten je izlazio do kraja godine, dokad je trajala i prva sjednica Koncila.

Kad je nakon smrti pape Ivana XXIII. 21. lipnja izabran novi papa - Pavao VI., fra Zorislav Lajoš i njegovi suradnici pripremili su i, ovaj put u tiskari, otisnuli prigodnu brošuru U ime Gospodnje Habemus Papam - imamo Papu. Premda sama brošura nema nadnevka niti se u impresumu navodi gdje je tiskana, u Glasu Koncila stoji da je izašla 30. lipnja 1963. u tiskari „Vjesnik” u nakladi od 40.000 primjeraka. ${ }^{74} \mathrm{U}$ međuvremenu su kaptolski franjevci, kako tvrdi fra Bonaventura Duda, dali do znanja nadbiskupu Šeperu da ne mogu nastaviti s izdavanjem Glasa s Koncila te mu predložili da taj posao povjeri nekome drugom. ${ }^{75}$ Stoga je u rujnu 1963. nadbiskup Šeper osnovao novi list, Glas Koncila, i nadbiskupskoga kancelara Dragutina Hrena imenovao njegovim odgovornim urednikom ${ }^{76}$, dok je službu glavnoga urednika de facto

${ }_{69}$ Bonaventura DUDA, „I tako je počelo”, Glas Koncila, 8. 10. 1972., 2-3.

70 „Prvi je broj Glasa s Koncila umnožen u 5.000 primjeraka, te je nakon potražnje umnoženo još tisuću, a onda je naklada počela rasti, da bi do kraja zasjedanja, tj. do 11. broja povećana na 25.000 primjeraka.” MATAUŠIĆ, „Prihvat Drugog vatikanskog koncila u Hrvatskoj na primjeru katoličkog tiska i odnosa Crkve prema medijima”, 504, bilj. 14.

71 „Prvi broj naišao je na neočekivani prihvat. Još ne bijahu prve četiri tisuće ni raznesene Zagrebom, već stigoše prvi naručitelji. Mislim da je prvi došao tražiti još isusovački sakristan. Otisnemo nove četiri tisuće. I još toliko. Više nije izdržao ni ciklostil ni njegovi suradnici. Kod toga se broja - 12.000 - ostalo do kraja.” Bonaventura DUDA, „I tako je počelo”, Glas Koncila, 8. 10. 1972., 3 .

72 „Ljetopis Glasa Koncila”, Glas Koncila, 8. 10. 1972., 3.

73 MATAUŠIĆ, „Prihvat Drugog vatikanskog koncila u Hrvatskoj na primjeru katoličkog tiska i odnosa Crkve prema medijima”, 504, bilj. 14.

74 „Ljetopis Glasa Koncila”, Glas Koncila, 8. 10. 1972., 3.

75 Usp. DUDA, „Prihvat II. Vatikanskog koncila u Hrvatskoj (II)”, 259.

76 NAZ, Ostavština Franje Šepera, kut. 48, korice 228, Odluka o imenovanju Dragutina Hrena glavnim i odgovornim urednikom Glasa s Koncila, br. 118/pr., 10. 9. 1963. 
preuzeo svećenik Vladimir Pavlinić, kojemu je nadbiskup Šeper dekretom povjerio „tehničko vodstvo i svu organizaciju oko izdavanja lista”. ${ }^{77}$ Službenu odluku o osnivanju Glasa Koncila Šeper je potpisao po povratku sa zasjedanja Koncila u Vatikanu 31. prosinca 1963., nakon što je već bilo tiskano prvih šest brojeva novoga lista, koji je u to vrijeme izlazio kao dvotjednik. ${ }^{78}$ Od 1964. za odgovornoga urednika imenovan je novoimenovani pomoćni zagrebački biskup Franjo Kuharić. ${ }^{79}$

Osim urednika Vladimira Pavlinića, jezgru uredništva od početka izdavanja Glasa Koncila čini i tadašnji župnik u Sošicama Živko Kustić, kao suradnici prvoga broja od 29. rujna 1963. navode se i Mijo Škvorc, Bonaventura Duda, Zorislav Lajoš i Josip Ladika, a u „tehničku i organizacijsku pomoć” bili su uključeni Luka Perinić i Milostislav Ciko. ${ }^{80}$ Od jeseni 1963. i Tomislav Šagi-Bunić postaje članom uredništva, kao teološki savjetnik i redoviti suradnik $^{81}$, a najkasnije od početka veljače 1964. uredništvu će se kao stalna vanjska suradnica pridružiti i novinarka iz Rijeke Smiljana Rendić, najprije kao autorica rubrike „Mi, ovdje” s pseudonimom Berith, a kasnije i kao autorica brojnih drugih priloga, kronika i članaka, osobito s područja „vatikanistike” i vijesti iz svijeta.

Tijekom 60-ih godina u redakciji su bili i Gabrijel Đurak ${ }^{82}$, Luka Depolo ${ }^{83}$, lektor i redaktor Stjepan $\mathrm{Hosu}^{84}$ te novinar i enigmatičar Andrija Žic. ${ }^{85}$ No i mnogi teolozi koji nisu bili članovi uredništva sudjelovali su u kreiranju njegova sadržaja, pa i uređivačke politike, poput Josipa Turčinovića, Vjekoslava Bajsića, Ivana Goluba i drugih. Osim uredništva, list je na temelju spomenute odluke o utemeljenju od 31. prosinca 1963. dobio i Direktorij, svojevrsni „upravni odbor”, u koji su imenovani Vladimir Stanković, Milostislav Ciko i Franjo Grundler, a upraviteljem lista imenovan je Sibe Zaninović. Direktorij je djelovao samo do sredine 1964., nakon čega se više nije sastajao. Novim je upraviteljem (direk-

77 Usp. „Ljetopis Glasa Koncila”, Glas Koncila, 8. 10. 1972., 3; MIKLENIĆ, „Kardinal Franjo Šeper - utemeljitelj katoličkog lista Glas Koncila", 256; AKMADŽA, Katolička crkva u komunističkoj Hrvatskoj, 301.

78 Arhiv Glasa Koncila, Ur. br. 0/1963, Odluka o izdavanju Glasa Koncila br. 3130/1963, 31. 12. 1963., preslika.

79 Usp. Impresum, Glas Koncila, 10. 5. 1964., 2.

80 „Ljetopis Glasa Koncila”, Glas Koncila, 8. 10. 1972., 3.

81 MIKLENIĆ, Pogledi u Glas Koncila, 195.

82 U uredništvu lista od 1966., među ostalim i kao voditelj rubrika „Tko je moj bližnji?” i „Iz naših krajeva”, a od 1968. pa do svoje smrti 1974. bio je i glavni urednik mjesečnika za djecu Mali koncil.

83 U listu je surađivao i kao student, a u uredništvo ulazi nakon svećeničkoga ređenja 1966. godine. Najprije je bio voditelj rubrike „Braća naša zaboravljena”, a od 1974. glavni urednik Maloga koncila.

${ }_{84}$ U listu, kao lektor i redaktor, djeluje već od 1963. godine. Mnogi upravo njemu pripisuju zasluge za jezične standarde koje je list postavio, primjerice Ivan Golub: „Glas Koncila čuvat će čist hrvatski jezik, otporan na nasilnu srpskohrvaštinu. Lektor je nekoć moj gimnazijski profesor Stjepan Hosu, znalac jezika." GOLUB, Običan čovjek, 192. Usp. MIKLENIĆ, Pogledi u Glas Koncila, 177.

${ }_{85}$ MIKLENIĆ, Pogledi u Glas Koncila, 211-212. 
torom) 24. siječnja 1965. umjesto Zaninovića imenovan Josip Ladika, koji je i nekoliko mjeseci prije imenovanja stvarno vršio tu službu. ${ }^{86}$

Redakcija lista najprije je bila smještena u jednoj prostoriji, svećeničkom prenoćištu, u Bogoslovnom sjemeništu na zagrebačkom Kaptolu 29 ${ }^{87}$, no ubrzo je sjedište lista preseljeno u kuriju kanonika Stjepana Bakšića, koji je preminuo 7. kolovoza 1963., na adresi Kaptol 8, gdje je ostalo sve do danas. ${ }^{88}$

Prvi broj Glasa Koncila tiskan je 3. listopada 1963. u tiskari „Informator” 89 u nakladi od 40.000 primjeraka, no naklada je vrlo brzo počela rasti, pa je do kraja 1963. udvostručena, do kraja 60-ih godina dosegnula je oko 180.000 primjeraka, a božićni broj 1969. tiskan je u više od 245.000 primjeraka. ${ }^{90}$ List je poštom distribuiran ne samo u zemlji, nego se prodavao i „na svim kontinentima (Evropa, Amerika, Australija, Afrika)". ${ }^{11} \mathrm{Na}$ upit Sekretarijata za informacije Izvršnoga vijeća Sabora od 26. prosinca 1972..$^{92}$, Glas Koncila dostavio je i precizne podatke o stranim zemljama u koje se list dostavlja, zajedno s pripadajućim brojem primjeraka. Iz toga dopisa za 1972. doznajemo da se Glas Koncila dostavljao u Austriju (1272), Australiju (124), Argentinu (28), Belgiju (83), Čehoslovačku (20), Englesku (6), Francusku (260), Nizozemsku (100), Italiju (94), Kanadu (772), Saveznu Republiku Njemačku (8082), Norvešku (44), Novi Zeland (4), Švedsku (70), Švicarsku (920) te Sjedinjene Američke Države (252 primjerka po broju) ${ }^{93}$

Osim osnovnoga lista, redakcija je iz rubrike „Vama djeco”, koja je pokrenuta za Božić 1964., od ožujka 1966. osnovala i zasebni list za djecu i mlade Mali koncil, najprije kao podlistak, a potom i kao samostalni mjesečnik. U početku ga uređuje Marko Majstorović, a od 1968. glavni mu je urednik fra Gabrijel Đurak. List ima početnu nakladu od oko 80.000 primjeraka po broju, no već 1967. povećala se na $92.000 .^{94}$

Usporedimo li nakladu Glasa Koncila s drugim vjerskim listovima u zemlji, lako ćemo zaključiti da je riječ o najčitanijem i najutjecajnijem vjerskom listu u Jugoslaviji u to vrijeme. Primjerice, po podacima koje je za 1968. objavilo glasilo Saveza novinara Jugoslavije Naša štampa, prosječna naklada po broju za Glas Koncila iznosi 170.000 primjeraka, Mali Koncil tiskao se u 80.000 pri-

86 Isto, 31-32.

87 Vladimir PAVLINIĆ, „Odnekud s višeg mjesta došao je ‘Stop””, Glas Koncila, 8. 8. 1993., 4.

88 MIKLENIĆ, „Kardinal Franjo Šeper - utemeljitelj katoličkog lista Glas Koncila”, 259. Informaciju o promjeni adrese uredništva vidi u: „Obavijesti”, Glas Koncila, 3. 11. 1963., 16.

89 Vladimir PAVLINIĆ, „Odnekud s višeg mjesta došao je 'Stop””, Glas Koncila, 8. 8. 1993. 4.

90 Arhiv Glasa Koncila, Ur. br. 5/1972, Podaci o nakladi, 12. 2. 1972.

91 Arhiv Glasa Koncila, Ur. br. 1/1972, Odgovor direktora Glasa Koncila Josipa Ladike „Jugoreklam"-u, 15. 1. 1972.

92 Arhiv Glasa Koncila, Ur. br. 2/1973, Upit Sekretarijata za informacije Izvršnog vijeća Sabora SR Hrvatske Glasu Koncila o nakladi za inozemstvo od 26. 12. 1972.

93 Arhiv Glasa Koncila, Ur. br. 3/1973, Dopis Glasa Koncila Sekretarijatu za informacije IV Sabora o nakladi za inozemstvo od 11. 1. 1973.

94 NOVAK, Hrvatsko novinarstvo u 20. stoljeću, 599. 
mjeraka, ljubljanska Družina imala je nakladu od 126.000 primjeraka, Pravoslavni misionar 50.000, Veritas i Glasnik Srca Isusova po 40.000, Blagovest 23.000, Marija 16.000 primjeraka. ${ }^{95}$

Ako bismo podatke o nakladi Glasa Koncila usporedili s nakladom drugih javnih glasila u zemlji, bilo bi najprimjerenije tu usporedbu napraviti s tadašnjim tjednicima. Pritom je naklada Glasa Koncila primjerice manja od tada vrlo popularnog i čitanog Vjesnika u srijedu, koji 1966. izlazi u prosječnoj nakladi od 300.000 primjeraka ${ }^{96}$, ali veća od Hrvatskoga tjednika, čiji je posljednji broj prije ukidanja 1971. tiskan u nakladi od 130.000 primjeraka. ${ }^{97}$ Premda usporedba s dnevnicima, iz više razloga, nije do kraja primjerena, donosimo i podatke o nakladi nekih poznatijih dnevnih listova iz toga vreme-

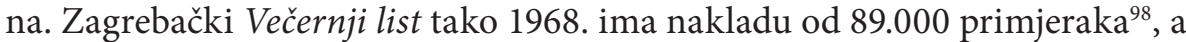
Vjesnik se 1969. tiska u nakladi od oko 100.000 primjeraka. ${ }^{99}$

No, za razliku od tih listova, Glas Koncila nije imao pristup redovitim kanalima distribucije preko kioska i drugih prodajnih mjesta, nego se distribuirao isključivo poštanskim pošiljkama pretplatnicima te preko crkvene prodajne mreže. Naime, vlasti su odbile višekratne zahtjeve toga lista da mu se omogući prodaja distribucijskim kanalima „Vjesnika”, premda je to poduzeće bilo sklono udovoljiti njihovoj molbi uz uvjet da se Glas Koncila tiska u njihovoj tiskari. No Komisija za vjerska pitanja na svojim je sjednicama u ožujku i travnju 1966. zaključila „da ne bi bilo politički oportuno da se to dozvoli”, a sličan su stav zauzeli i Izvršno vijeće Sabora Socijalističke Republike Hrvatske te Služba za informacije Centralnoga komiteta Saveza komunista Hrvatske. ${ }^{100}$

Državne su vlasti i prije pokretanja Glasa Koncila došle do informacija o planovima Crkve da pokrene svoje novine. Na sjednici Komisije za vjerska pitanja 10. svibnja 1963. predstavljena je i raspravljena Informacija o povećanoj izdavačkoj djelatnosti vjerskih zajednica, u kojoj se najavljuje i mogućnost da Katolička crkva pokrene svoj dnevni list:

„Informirani smo da zagrebački Kaptol priprema izdavanje jednog katoličkog lista koji bi izlazio za prvo vrijeme kao tjednik, a kasnije kao dnevno glasilo za katoličke vjernike. Izdavač bi bilo Hrvatsko književno ĆMD [ćirilo-metodsko društvo] Zagreb, a uređivao bi ga tehnički tajnik ĆMD-a Luka Perinić. Pripreme za izlazak tih novina su izvršene, stvoren je fond, i obezbeđena materijalna sredstva. Episkopat je zatražio od svih župa i svećenika određena materijalna

95 „Podaci o vjerskim časopisima u Jugoslaviji za 1968.”, Glas Koncila, 22. 2. 1970., 7.

96 NOVAK, Hrvatsko novinarstvo u 20. stoljeću, 571.

97 Isto, 664.

98 Isto, 565.

99 Isto, 668.

100 HR-HDA-310-KOVZ, kut. 67, Pov. br. 63/1966, Zapisnik sjednice Komisije, 22. 3. 1966 ; HR-HDA-310-KOVZ, Zapisnici Komisije za vjerska pitanja (Knjiga 9), „Problemi i stavovi iz oblasti odnosa s vjerskim zajednicama", Prilog Zapisniku sjednice Komisije, 8. 4. 1967., 3; HRHDA-310-KOVZ, Zapisnici Komisije za vjerska pitanja (Knjiga 9), Prilog 7 Zapisniku sjednice Komisije, 30. 10. 1967., 3. 
sredstva za fond ovih novina. Većina župnika do sada se odazvala, a poneki su prodavali vrijedne stvari uključujući automobile, a dobiveni novac priložili fondu. Novine bi se štampale u 200.000 primjeraka, a distribucija bi se odvijala tako da svi župnici preplate svoje vjernike na dotičnu novinu. Vjernici koji iz materijalnih razloga ne bi mogli plaćati dobivali bi novine besplatno, a troškovi bi bili refundirani iz pomenutog fonda. Navodno, za izdavanje lista, pored izvršenih tehničkih priprema u zemlji, nabavljena je i kompletna štamparija u Austriji i samo se očekuje na njenu dopremu i montiranje u prostorijama ĆMD-a u Zagrebu."101

Premda je u tim tvrdnjama bilo i informacija koje će se poslije pokazati pouzdanima - poput uključenosti Luke Perinića u kasnije stvaranje lista te načina njegove distribucije - većina navedenih najava ipak se nije ostvarila: niti je list postao dnevnik, niti je u idućim godinama i desetljećima pokrenuo vlastitu tiskaru, a čini se da su i tvrdnje o velikoj materijalnoj podlozi budućega lista bile pretjerane. Naime, prvi glavni urednik Glasa Koncila Vladimir Pavlinić tvrdi da je od nadbiskupa Šepera dobio inicijalna sredstva u iznosu od „pola milijuna dinara” 102 za tiskanje prvih brojeva, ali i on i budući urednik Živko Kustić u više su navrata isticali da je sve otad list živio isključivo od vlastitih prihoda, odnosno prodaje, te „za sve druge godine svoga postojanja i djelovanja nije ni od koga, ni od koje crkvene, državne ili bilo koje druge ustanove, nikad primao pomoć za svoje izlaženje”. ${ }^{103}$

Mogli bismo zaključiti da je uspjeh „na tržištu” obnovljeni katolički tisak dugovao više svojoj prihvaćenosti od publike nego materijalnim potporama koje bi u to vrijeme primao.

\section{Prihvaćenost obnovljenoga katoličkog tiska od publike}

Kako smo uvodno istaknuli, početak 60 -ih godina Katolička crkva u $\mathrm{Hr}$ vatskoj dočekala je praktički bez postojanja vlastitoga tiska, s tek nekoliko službenih (nad)biskupijskih vjesnika namijenjenih potrebama svećenstva. No već u prvim godinama obnovljeni katolički tisak doživljava velik rast broja listova i naklade svojih izdanja. Prema podacima koje je prikupljala i analizirala Komisija za vjerska pitanja te ih 1966. sažela u dokumentu Izdavačka djelatnost vjerskih zajednica u SRH, 1961. ukupna godišnja naklada svih tiskanih izdanja Katoličke crkve u Hrvatskoj iznosila je 250.000 primjeraka, 1962. porasla je na $1.800 .000,1963$. na 3 milijuna, 1964. na 5 milijuna, a 1965. na čak 8.250.000 primjeraka. Za usporedbu, u spomenutim godinama naklade listova drugih vjerskih zajednica u Hrvatskoj ostale su praktički nepromijenjene: Srpska pravoslavna crkva tiskala je po 1500, Islamska vjerska zajednica 1000,

101 HR-HDA-310-KOVZ, Zapisnici sa sjednica Komisije za vjerska pitanja (Knjiga 5), Zapisnik sa sjednice Komisije, 10. 5. 1963., 2-3.

102 Vladimir PAVLINIĆ, „Odnekud s višeg mjesta došao je 'Stop”', Glas Koncila, 8. 8. 1993., 4.

103 Živko KUSTIĆ, „U matičnom tijeku hrvatskoga katolištva”, Glas Koncila, 8. 8. 1993., 5. 
Jehovini svjedoci 5000, baptisti 2000, a adventisti 1000 primjeraka svojih listova godišnje. ${ }^{104}$

Komisija je redovito pratila ne samo nakladu crkvenih listova nego i kadrovske i materijalne uvjete u kojima je taj tisak stvaran i distribuiran, kao i opremu i sadržaj objavljenih listova. Tako primjerice sredinom 60 -ih zaključuje da je njihova „opća karakteristika” to da je

„[...] sveobuhvatna, dvosmislena i crkveno obojena, a tematika koju tretira među čitaocima interesantna i afirmira se kao značajni instrument Crkve oko koje se skuplja sve više građana. Na taj način Crkva tretira i ulazi u sve oblike ljudskog života s tendencijom njenog idejnog utjecaja na vjernike. Izbjegavajući direktne političke napade na naš društveno politički sistem, ali puna aluzija i često netačnog i tendencioznog prikazivanja pojedinih zbivanja i događaja iz naše zemlje, katolička štampa na njoj svojstveni način naturava čitaocima svoja shvaćanja o najvažnijim pitanjima društvenog života, koja su vrlo često u suprotnosti s našim shvaćanjima". 105

U drugoj polovini 60-ih, po ocjenama Savezne komisije za vjerska pitanja, katolički tisak sve više zadire u društvene i političke teme te se „više ne može govoriti o verskoj štampi”, nego o tisku vjerskih zajednica koji „tretira sve društvene problema sa klerikalnog stanovišta". ${ }^{106}$ Komisija također procjenjuje da su različite teme u katoličkom tisku prezentirane „tako da povećaju naklonost prema Katoličkoj crkvi i da kod vjernika utječu na formiranje političkih stavova [istaknuto u izvorniku] koji odgovaraju stavovima Katoličke Crkve i koji često nisu i ne mogu biti u skladu s našim pozitivnim zakonodavstvom i našim shvaćanjima i stremljenjima, jer polaze s ideološki sasvim suprotnih pozicija". ${ }^{107}$

Uočava se i da su izdanja „štampana na kvalitetnijem papiru, bolje su tehnički opremljena i snabdjevena sa više ilustracija i slika u raznim bojama” te da „Katolička crkva raspolaže sa solidnim kadrovima kako oko uređenja i pripremanja pojedinih listova i publikacija tako i oko raspačavanja, gdje su angažirani pored svećenika i crkveni odbori, ministranti, crkveni pjevački zborovi i najaktivniji vjernici, pa razumljivo da na taj način katolička štampa stiže i u one predjele zemlje gdje se ne raspačava naša štampa". ${ }^{108}$ Drugdje se precizira da u distribuciji crkvenih izdanja , aktivno učestvuje oko 2.000 svećenika i redovnika, preko 3.000 časnih sestara, zatim brojni odbori, ministranti, članovi

${ }^{104}$ HR-HDA-310-KOVZ, kut. 67, Pov. br. 64/1966, Informacija o izdavačkoj djelatnosti vjerskih zajednica u SRH od 26. 5. 1966., 1.

${ }^{105}$ HR-HDA-310-KOVZ, Zapisnici Komisije za vjerska pitanja (Knjiga 9), Prilog 5 Sjednici Komisije od 8. 4. 1967., 4.

106 HR-HDA-310-KOVZ, kut. 78, Pov. br. 195/1968, Analiza Savezne komisije za vjerska pitanja „Neka aktuelna pitanja verskih zajednica”, 11.

107 HR-HDA-310-KOVZ, kut. 67, Pov. br. 64/1966, Informacija o izdavačkoj djelatnosti vjerskih zajednica u SRH od 26. 5. 1966., 7.

${ }^{108}$ HR-HDA-310-KOVZ, Zapisnici Komisije za vjerska pitanja (Knjiga 9), Prilog 5 Zapisniku sjednice Komisije od 8. 4. 1967., 1-2. 
crkvenih pjevačkih zborova, za vrijeme ljetnih školskih praznika oko 2.500 sjemeništaraca i bogoslova i najaktivniji vjernici"109 te donose i neke konkretne brojke s terena:

„U selu Brušani (kod Gospića), gdje ima 137 domaćinstava, prodaje se 80 primjeraka Glasa Koncila, 30 primjeraka Glasnika srca Isusova i Marijina, 20 primjeraka Bakarskih zvona, a samo 3 primjerka Borbe. Druga štampa u ovo selo ne dolazi. U Pag, koji ima 2.300 stanovnika, na katoličku štampu pretplaćeno je 610 lica [...] u Rijeci su vrlo popularni (među vjernicima) vjerski listovi: Glasnik sv. Antuna Padovanskog i Glasnik srca Isusova i Marijina, Glas Koncila je svaki put formalno razgrabljen, pa se neprestano povećava broj prodanih primjeraka. U selu Brkač, Motovu i Kaldir (okolica Rijeke), dolazi po 150 primjeraka vjerske štampe, a samo 2 primjerka Borbe i 7 primjeraka Glasa Istre. U Vrbniku na Krku prodaje se preko 100 primjeraka Glasa Koncila, a svega 2 primjerka Borbe. U okolici Zadra (prema podacima Kotarskog Komiteta SK koji je analizirao čitanje dnevne štampe na svom općinskom području) raspačava se 1144 primjerka Slobodne Dalmacije, 1635 primjeraka Borbe, 1699 primjeraka Vjesnika i 2302 primjerka Glasa Koncila." ${ }^{110}$

Distribucija katoličkoga tiska bila je predmetom interesa ne samo Komisije za vjerska pitanja nego i drugih tijela državnih vlasti, pa i Službe državne sigurnosti. Primjerice, u uredovnoj zabilješci od 18. listopada 1963. o razgovoru s tadašnjim župnikom u Samoboru Franjom Kuharićem službenik koji je obavio razgovor izvješćuje Službu državne sigurnosti Zagreb i o tome da „u pogledu vjerske štampe Kuharić uzima 100 komada Glasa Koncila i 200 komada Glasnika sv. Antuna” te da se župnik žalio „da je to premalen broj za tako veliku župu kao što je Samobor". ${ }^{111}$

Komisija je stoga u više navrata preporučivala da bi „sve većem prodoru vjerske štampe naročito u sela trebalo suprotstaviti borbu za čitaoce naših dnevnih i tjednih listova, a društveno političke organizacije, naročito SK [Savez komunista] i SSRN [Socijalistički savez radnog naroda] bi trebale obratiti daleko veću pažnju ovoj vrsti aktivnosti Katoličke crkve”. Pritom se dodaje da „na drugoj strani mi imamo instituciju Filozofski fakultet, časopise i redakcije koje se bave pitanjima filozofije, onda tim institucijama treba da se ta građa i ta materija doturi pa neka one reagiraju na te stvari. Ako se radi o svakodnevnim stvarima, onda neka one dođu do uredništva 'Vjesnika' ili 'Borbe' da bi oni reagirali na odgovarajući način na te pojave". ${ }^{112}$

Potkraj 60-ih godina ipak se osjeća posustajanje rasta naklade katoličkoga tiska u Hrvatskoj. Prema izvješću koje je u veljači 1967. priredilo Javno tuži-

109 HR-HDA-310-KOVZ, kut. 67, Pov. br. 64/1966, Informacija o izdavačkoj djelatnosti vjerskih zajednica u SRH od 26. 5. 1966., 9.

110 Isto, 13-14.

111 NAZ, Ostavština Franje Kuharića, „Dosje UDB-e i Službe državne sigurnosti o Franji Kuhariću”, 131-132.

112 HR-HDA-310-KOVZ, Zapisnici sa sjednica Komisije (Knjiga 6), Zapisnik sa sjednice 18 XI. 1964., 15. 
laštvo Hrvatske, „tiraž vjerske štampe iznosio je 1966. godine oko 9.000.000 primjeraka, i bilježi neznatan porast prema 1965. godini za oko 500.000 primjeraka”. ${ }^{113}$ Dvije godine poslije Komisija za vjerska pitanja procjenjuje da „intenzivnost vjerskog života” Katoličke crkve potaknuta Drugim vatikanskim koncilom „izgleda da je već prešla svoju kulminaciju”:

„Isto tako, već je u priličnoj mjeri popunjen i onaj slobodni 'prostor' koji se pojavio nakon otklanjanja administrativnih mjera, a i utažena je početna 'glad' za vjerskom štampom, pločama i sl., pa je na izmaku prvobitni impuls koji je pratio vjerski život, a koji je jednim svojim dijelom nastao i kao protuteža i reakcija na dugogodišnje zabrane." ${ }^{114}$

I u jednom kasnijem izvješću Komisija za vjerska pitanja zaključuje da „nakon ekspanzije vjerske štampe (koje ranije gotovo nije ni bilo) [...] neposredno nakon Drugog koncila, u posljednje dvije do tri godine aktivnosti Crkve i intenzitet vjerskog života opali su i zadržali se na 'normalnoj' razini (naklada vjerske štampe opada - npr. Glas Koncila 1968. god 170.000, a posljednji broj 3/1972 - 143.000)". ${ }^{115}$

I Glas Koncila početkom 70-ih godina uočava i priznaje tendenciju pada interesa za katolički tisak, odnosno da „ustrajno opada broj ozbiljnih čitatelja vjerska tiska (kao, uostalom, tiska uopće)", te i sam priznaje da nema odgovor na pitanje zašto je to tako, ali primjećuje: „Nešto se događa, nešto što bi nas moralo barem zabrinuti."116 U jednom prijašnjem tekstu list tu tendenciju povezuje s pojavom da „katoličko novinstvo postaje sve više konformističko, da biskupi vrše nad njim sve strožu cenzuru, da sve manje dopuštaju katoličkim novinarima slobodno pisati, slobodno tretirati goruće probleme Crkve", pa to novinarstvo „postaje sve više 'službeno', a sve manje hrabro, otvoreno, konstruktivno”, riječju - „dosadno”. ${ }^{117}$

I neki drugi autori pad naklade katoličkoga tiska povezuju sa sve ozbiljnijim kritikama koje su u drugoj polovini 60-ih godina određeni crkveni krugovi, pa i crkvene vlasti, iznosili na račun pisanja i uređivačke koncepcije dijela katoličkoga tiska. ${ }^{118}$ Takvu tezu u prikazu važnijih trenutaka u povijesti Glasa Koncila iznosi i njegov donedavni urednik Ivan Miklenić kad ističe da se izlazak iz tiska brošure Čedomila Čekade Proigrana šansa, „koja je neobjektivno optužila Glas Koncila za progresizam”, odrazio „na pad naklade”119. Da je

${ }_{113}$ HR-HDA-310-KOVZ, Pov. br. 82/1967, Izvješće o radu u vezi sa štampom u 1966. godini od 8. 2. 1967., 2 .

114 HR-HDA-310-KOVZ, kut. 83, Pov. br. 130/1969, Neke karakteristike odnosa i procesa u Katoličkoj crkvi na području SR Hrvatske, 5. 9. 1969., 16.

115 HR-HDA-310-KOVZ, kut. 94, Pov. br. 38/1972, Izvještaj o nekim aktualnim pitanjima iz odnosa prema vjerskim zajednicama u SR Hrvatskoj od 15. 2. 1972.

116 „Jedno iščezavanje zanimanja”, Glas Koncila, 16. 4. 1972., 2.

117 „Katoličke novine ne vrijede ako ne uznemiruju”, Glas Koncila, 5. 4. 1970., 3.

118 Usp. MIKIĆ, AKMADŽA, „Kritike crkvenih i vjerničkih krugova na sadržaj Glasa Koncila od 1963. do 1972. godine".

119 MIKLENIĆ, Pogledi u Glas Koncila, 131, 215. 
do pada naklade katoličkoga tiska krajem 60-ih došlo „zahvaljujući jednim dijelom javnim napadima samih svećenika na njihov progresizam" smatra i novinar i publicist Ćiril Petešić. ${ }^{120}$

\section{Zaključak}

Obnova katoličkoga tiska u Hrvatskoj 60-ih godina XX. stoljeća rezultat je nekoliko paralelnih procesa koji su obilježili život Katoličke crkve i društva toga vremena, a ponajviše je plod normalizacije odnosa između crkvenih i državnih vlasti, do koje je u to vrijeme došlo na nacionalnoj, ali i međunarodnoj razini. Proces obnove Katoličke crkve potaknut Drugim vatikanskom koncilom s jedne strane te želja jugoslavenskih vlasti da normaliziraju odnose s Crkvom u tadašnjoj Jugoslaviji, ali i obnove 1952. jednostrano prekinute diplomatske odnose sa Svetom Stolicom s druge strane otvorili su mogućnost da Crkva u Hrvatskoj obnovi i neke svoje javne/društvene djelatnosti koje su joj od 1945. bile sustavno uskraćivane, među kojima je istaknuto mjesto zauzelo ponovno pokretanje njezina tiska, koji je država u drugoj polovini 40-ih ugušila. Da je to preduvjet normalizacije odnosa Crkve i države, Crkva je, i ona u Hrvatskoj i Sveta Stolica, u više navrata upozoravala predstavnike državnih vlasti. Stoga su vlasti procijenile da zbog postizanja cilja, uspostave odnosa s Crkvom i diplomatskih odnosa sa Svetom Stolicom, trebaju „promijeniti taktiku" prema Crkvi te joj omogućiti pokretanje vlastitoga tiska, ali i budno pratiti da taj tisak ne zalazi na društveno i političko područje. Tu je priliku Crkva 60-ih godina uspješno iskoristila, a obnovljeni katolički tisak naišao je na velik interes publike te se u samo nekoliko godina umnožio i broj osnovanih listova i njihove naklade: sa 250.000 primjeraka 1961. na oko 9 milijuna tiskanih primjeraka katoličkih listova 1966., nakon čega je ipak došlo do postupne stagnacije u nakladi katoličkoga tiska.

Kao najvažniji katolički list osnovan u to vrijeme profilirao se Glas Koncila, koji je nastao kao plod suradnje i kontakata tadašnje nove generacije katoličkih teologa, uglavnom okupljenih na Katoličkom bogoslovnom fakultetu u Zagrebu, i istaknutijih vjernika laika koji su bili aktivni u predratnom katoličkom tisku, ugušenom 1945. godine. Glas Koncila uspio se naglo razviti i opstati među ostalim i zbog želje komunističkih vlasti da preko njega (i drugih vjerskih listova) vjernicima i svećenstvu budu dostupne informacije s Drugoga vatikanskoga koncila, čije su ideje i odluke smatrali progresivnima. Drugo veliko središte katoličkoga izdavaštva formirat će se u drugoj polovini 60-ih u sklopu novoutemeljene Kršćanske sadašnjosti, a i brojne su redovničke zajednice iskoristile povoljan trenutak te pokrenule ili obnovile neka svoja tiskana izdanja, dok su teološka učilišta diljem Hrvatske pokrenula svoje stručne i znanstvene časopise. Promatrano razdoblje obilježio je i procvat župskih listova, koji su zadovoljavali potrebe vjernika za lokalnim crkvenim informacijama.

${ }^{120}$ PETEŠIĆ, Što se događa u Katoličkoj crkvi u Hrvatskoj, 20. 
Državne su vlasti pomno pratile sve te procese, analizirale pokrenute listove i uvjete u kojima su oni stvarani, te su nastojale odgovoriti na izazove koje je obnovljeni tisak pred njih postavljao, ograničavajući njegov utjecaj i onemogućavajući mu da se preko određene mjere koju su smatrali prihvatljivom bavi društvenim i političkim temama.

\section{Arhivsko gradivo}

Arhiv Glasa Koncila, Zagreb.

HR-HDA-310-KOVZ: Hrvatska, Hrvatski državni arhiv, Zagreb, fond 310, Komisija za odnose s vjerskim zajednicama Izvršnog vijeća Sabora Socijalističke Republike Hrvatske.

NAZ: Nadbiskupijski arhiv u Zagrebu, Zagreb:

- Ostavština Franje Kuharića.

- Ostavština Franje Šepera.

Osobni arhiv Vladimira Pavlinića, London, Ujedinjeno Kraljevstvo.

\section{Objavljeni izvori i tisak}

Glas Koncila (Zagreb), 1963-1964, 1970, 1972, 1993.

KISIĆ-KOLANOVIĆ, Nada. „Pisma zagrebačkog nadbiskupa Alojzija Stepinca predsjedniku Narodne vlade Hrvatske Vladimiru Bakariću godine 1945." Croatica Christiana Periodica 16 (1992), br. 29: 137-180.

Službeni list Federativne Narodne Republike Jugoslavije (Beograd), 45 (1960).

VOJNOVIĆ, Branislava, prir. Zapisnici Politbiroa Centralnoga komiteta Komunističke partije Hrvatske 1945. - 1952., sv. 1: 1945. - 1948. Zagreb: Hrvatski državni arhiv, 2005.

\section{Literatura}

AKMADŽA, Miroslav. Katolička crkva u komunističkoj Hrvatskoj 1945. - 1980. Zagreb: Plejada; Hrvatski institut za povijest, Podružnica za povijest Slavonije, Srijema i Baranje, 2013.

AKMADŽA, Miroslav. Oduzimanje imovine Katoličkoj crkvi i crkveno-državni odnosi od 1945. do 1966. godine. Primjer Zagrebačke nadbiskupije. Zagreb: Društvo za povjesnicu Zagrebačke nadbiskupije „Tkalčić”, 2003.

AKMADŽA, Miroslav. „Uzroci prekida diplomatskih odnosa između Vatikana i Jugoslavije 1952. godine”. Croatica Christiana Periodica 27 (2003), br. 52: $171-202$.

ANCIĆ, Zvonimir. „Pregovori i ponovna uspostava diplomatskih odnosa između Vatikana i SFRJ”. Magistarski rad, Fakultet političkih znanosti Sveučilišta u Zagrebu, 2012. 
BAGARIĆ, Stipe. „Informativna sredstva Kršćanske sadašnjosti”. U: Nastanak i razvitak Kršćanske sadašnjosti. Zbornik radova sa znanstvenog simpozija o 40. obljetnici djelovanja, ur. Albert Turčinović. Zagreb: Kršćanska sadašnjost, 2010, 307-331.

BANAC, Ivo. Hrvati i Crkva. Kratka povijest hrvatskog katoličanstva u modernosti. Zagreb; Sarajevo: Profil; Svjetlo riječi, 2013.

CIFRAK, Mario. „Izdavačka djelatnost Kršćanske sadašnjosti kao vrijeme teologije". U: Nastanak i razvitak Kršćanske sadašnjosti. Zbornik radova sa znanstvenog simpozija o 40. obljetnici djelovanja, ur. Albert Turčinović. Zagreb: Kršćanska sadašnjost, 2010, 53-69.

DEVČIĆ, Ivan. „Mons. dr. Josip Šojat (1912. - 1996.)”. Senjski zbornik: prilozi za geografiju, etnologiju, gospodarstvo, povijest i kulturu 23 (1996), br. 1: 405-407. Pristup ostvaren 17. 5. 2021. https://hrcak.srce.hr/72134.

DUDA, Bonaventura. „Prihvat II. Vatikanskog koncila u Hrvatskoj (II). Fragmenti za buduće cjelovitije poruke”. Crkva u svijetu 31 (1996), br. 3: 251274.

GOLUB, Ivan. Običan čovjek. Zagreb: Naklada Ljevak, 2013.

KOŠIĆ, Vlado. „Recepcija Koncila u Hrvatskoj - uloga Kršćanske sadašnjosti u tome”. U: Nastanak i razvitak Kršćanske sadašnjosti. Zbornik radova sa znanstvenog simpozija o 40. obljetnici djelovanja, ur. Albert Turčinović. Zagreb: Kršćanska sadašnjost, 2010, 23-30.

KUSTIĆ, Živko. „Glas Koncila u pokoncilskom vremenu”. U: Jeke jednog Koncila, ur. Vlado Košić i Anton Peranić. Zagreb: Kršćanska sadašnjost, 1984, 121-152.

MATAUŠIĆ, Mirko J. „Katolički tisak u Zagrebačkoj nadbiskupiji”. U: Zagrebačka biskupija i Zagreb 1094. - 1994. Zbornik u čast kardinala Franje Kuharića, ur. Antun Škvorčević. Zagreb: Nadbiskupija zagrebačka; Katolički bogoslovni fakultet, 1995, 649-660.

MATAUŠIĆ, Mirko. „Prihvat Drugog vatikanskog koncila u Hrvatskoj na primjeru katoličkog tiska i odnosa Crkve prema medijima”. Časopis za suvremenu povijest 38 (2006), br. 2: 499-521.

MIHALJEVIĆ, Josip. „Liberalizacija i razvoj medija u komunističkoj Hrvatskoj 1960-ih i na početku 1970-ih". Društvena istraživanja 24 (2015), br. 2: 239-258.

MIKIĆ, Anto. „Crkveno i društveno značenje Glasa Koncila od 1963. do 1972.” Doktorska disertacija, Hrvatski studiji Sveučilišta u Zagrebu, 2016.

MIKIĆ, Anto. „Sudski postupci protiv katoličkog tiska u komunističkoj Hrvatskoj 1960-ih i 1970-ih". Časopis za suvremenu povijest 51 (2019), br. 1: 183-210.

MIKIĆ, Anto; AKMADŽA, Miroslav. „Kritike crkvenih i vjerničkih krugova na sadržaj Glasa Koncila od 1963. do 1972. godine”. Croatica Christiana Periodica 42 (2018), br. 82: 149-171. 
MIKLENIĆ, Ivan. „Kardinal Franjo Šeper - utemeljitelj katoličkog lista Glas Koncila”. U: Šeper. Veritatem facientes in caritate 3. Zbornik radova Međunarodnog simpozija, prir. Željko Tanjić. Zagreb: Glas Koncila; Kršćanska sadašnjost, 2003, 253-261.

MIKLENIĆ, Ivan. Pogledi u Glas Koncila. Zagreb: Glas Koncila, 2013.

MILIĆ, Zoran. „Gore srca. Katolički tjedni list 1946-1953.” Diplomski rad, Institut za teološku kulturu laika Katoličkog bogoslovnog fakulteta u Zagrebu, 2002.

NOVAK, Božidar. Hrvatsko novinarstvo u 20. stoljeću. Zagreb: Golden marketing - Tehnička knjiga, 2005.

PAVLINIĆ, Vladimir. „Katolička štampa u Hrvatskoj”. U: Mi Crkva i drugo. Zbornik bogoslovske tribine, prir. Ana Benc-Kiš i dr. Zagreb: Kršćanska sadašnjost, 1971, 63-78.

PETEŠIĆ, Ćiril. Što se događa u Katoličkoj crkvi u Hrvatskoj. Zagreb: Stvarnost, 1972.

RADELIĆ, Zdenko. Hrvatska u Jugoslaviji 1945. - 1991. Od zajedništva do razlaza. Zagreb: Školska knjiga; Hrvatski institut za povijest, 2006.

RADIĆ, Radmila. Država $i$ verske zajednice 1945-1970, knj. II. Beograd: Institut za noviju istoriju Srbije, 2002.

SRAKIĆ, Marin. „Urednici i suradnici Glasnika/Vjesnika Đakovačke i Srijemske biskupije od 1873. do 1997. godine”. Diacovensia 6 (1998), br. 1: 29-54. Pristup ostvaren 17. 3. 2021. https://hrcak.srce.hr/index.php?show=clanak\&id_clanak_jezik=63270.

ŠARIĆ, Tatjana. „Djelovanje Agitpropa prema književnom radu i izdavaštvu u NRH, 1945-1952." Radovi Zavoda za hrvatsku povijest Filozofskoga fakulteta Sveučilišta u Zagrebu 42 (2010), br. 1: 387-423. Pristup ostvaren 16. 9. 2021. https://hrcak.srce.hr/index.php?show=clanak\&id_clanak_jezik=94940.

TURČINOVIĆ, Josip. „Kršćanska sadašnjost u pokoncilskoj obnovi”. U: Jeke jednog Koncila, ur. Vlado Košić i Anton Peranić. Zagreb: Kršćanska sadašnjost, 1984, 153-184.

TURČINOVIĆ, Josip. Misao vjere. Zagreb: Kršćanska sadašnjost, 2010.

ZNIDARČIĆ, Lav. „Organizirano djelovanje katoličkih svjetovnjaka na području zagrebačke nadbiskupije (1852-1994)”. U: Zagrebačka biskupija $i$ Zagreb 1094. - 1994. Zbornik u čast kardinala Franje Kuharića, ur. Antun Škvorčević. Zagreb: Nadbiskupija zagrebačka; Katolički bogoslovni fakultet, 1995, 373-392.

ZOVKO, Tihonija. „Đakovačke tiskare i novine u razdoblju od 1853. do 1948. godine”. Knjižničarstvo 15-16 (2011/2012), br. 1-2: 35-52. Pristup ostvaren 12. 2. 2021. https://hrcak.srce.hr/file/348029. 


\section{Mrežni izvori}

„Franjevci Split, kratka povijest”. Franjevačka provincija Presvetog Otkupitelja - Split. Pristup ostvaren 15. 6. 2021. https://www.franjevci-split.hr/ kratka-povijest/.

„Povijest Glasnika Srca Isusova i Marijina”. Glasnik Srca Isusova i Marijina. Pristup ostvaren 23. 5. 2021. https://glasnik-sim.hr/povijest-glasnika/.

„Povijest Veritasa”. Veritas. Glasnik sv. Antuna Padovanskog. Pristup ostvaren 13. 6. 2021. https://www.veritas.hr/povijest-veritasa/.

„Zvona' proslavila zlatni jubilej”. Informativna katolička agencija. Pristup ostvaren 24. 5. 2021. https://ika.hkm.hr/novosti/zvona-proslavila-zlatni-jubilej/. 


\section{SUMMARY}

\section{The Restoration of the Catholic Press in Croatia in the 1960s}

Relying on the published literature and unpublished archival material, the authors of this paper analyse the phenomenon of the restoration of the Catholic press in Croatia in the 1960s, primarily in the context of the Church-state relations of that time. The process of renewing the Catholic Church, prompted by the Second Vatican Council and the desire of the Yugoslav authorities to normalise relations with the Church in the then Yugoslavia on the one hand, and the restoration of the severed diplomatic relations with the Holy See in 1952 on the other, opened the way for the possibility that the Church in Croatia could restore some of its public/social activities, which had been systematically denied since 1945. A prominent place in this process was the restoration of the Catholic press, which had been shut down by the state authorities in 1945. The Church successfully took advantage of this opportunity in the 1960s, and the restored Catholic press was received with great interest in the public. In only a few years, the number of established/restored publications grew, as did their circulations.

Key words: Catholic Church; communist authorities; Holy See-Yugoslavia relations; Catholic press; Glas Koncila (Voice of the Council) 